\title{
EVALUATION OF UNIVERSITY EMPLOYEES' WORK BEHAVIOURS PERFORMANCE VIA ENTROPY BASED TOPSIS METHODS
}

\author{
ÜNIVERSITE ÇALIŞANLARININ ISŞ DAVRANIȘI PERFORMANSLARININ ENTROPY \\ TABANLI TOPSIS YÖNTEMİ İLE DEĞERLENDIRILILMESI
}

DOI:10.17755/esosder.67295

\author{
Ayhan KARAKAŞ ${ }^{1}$ \\ Said KINGIR ${ }^{2}$ \\ Ahmet ÖZTEL ${ }^{3}$
}

\begin{abstract}
This study is aimed to measure the employees' job performance behavior via the entropy based TOPSIS methods. For this purpose, work behaviors; burnout, emotional labor, intention to leave, and job satisfaction scales are taken as assessment criteria and a questionnaire is applied on public university employees. Integrated evaluation of all criteria is vital for performance measurement. At this point multi-criteria decision-making methods present an appropriate framework. MCDM methods are very suitable decision tools for measuring employee's performance. This method is used in order to measure performance for not only the number of work but also the attitude according to business, enterprise, and people getting services. Considering the researches done via TOPSIS are few, this work contributes to the literature. Because of appropriate scales are in opposite directions, TOPSIS method accepted as a MCDM method is used to reduce all scales to only one value. As a result, applying TOPSIS method in terms of measuring employees' job performance can conduct to measure qualitative works converting into quantitative works.
\end{abstract}

Keywords: TOPSIS, Performance Management, Employee Evaluation

\section{Öz}

Bu çalışmanın amacı, entropy tabanlı TOPSİS yöntemi ile çalışanların iş davranışı performansının ölçülmesidir. $\mathrm{Bu}$ amaçla iş davranışlarından; tükenmişlik, duygusal emek, işten ayrılma niyeti ve iş tatmini ölçekleri değerlendirme kriteri kabul edilerek bir kamu üniversitesi çalışanlarına anket uygulanmıştır. Tüm kriterlerin bütünleşik olarak değerlendirilmesi performans ölçümü için hayati öneme sahiptir. Bu açıdan bakıldığında, çok kriterli karar verme yöntemleri uygun bir çatı sunmaktadır. Çok kriterli karar verme yöntemleri insan kaynakları alanında performans değerlemede kullanılmaktadır. Performans değerlemeyi sadece yapılan iş sayısına göre değil, işletmeye karşı, işe karşı, hizmet verilen kişilere karşı tutumlara göre ölçmek amacıyla bu yöntem kullanılmıştır. TOPSİS yöntemi ile yapılan çalışmaların az olduğu dikkate alınırsa, literatüre katkı sağlayacağı düşünülmektedir. Ölçeklerdeki en uygun durumlar, zıt yönlü olduğu için bu ölçekleri bir tek değere indirgemek için çok kriterli karar verme yöntemlerinden biri olarak kabul edilen TOPSIS yöntemi uygulaması sonucunda, iş davranışları performans ölçümü konusunda, nitel çabaların nicel hale getirilerek ölçülmesi bağlamında katkı sağladığ 1 düşünülmektedir.

Anahtar Kelimeler: TOPSIS, Performans Yönetimi, Çalışan Değerlendirme

\footnotetext{
${ }^{1}$ Yrd.Doç.Dr., Bartın Üniversitesi, iïBF Turizm İşletmeciliği Bölümü, ayhankarakas74@gmail.com

${ }^{2}$ Prof.Dr., Bartın Üniversitesi, IïBF, saidkingir@hotmail.com

${ }^{3}$ Bartın Üniversitesi, iỉBF İşletme Bölümü, ahmetoztel@gmail.com
} 


\section{Introduction}

Performance evaluation in companies is one of the important functions for Human Resources Management. Thanks to technological development and increase in competition, companies have to ideally prepare its human resources and to achieve the highest efficiency with these educated human sources in order to score over its competitors. In this aspect, Human Resource is mentioned as a strategic element of a company. In service industry, this strategic element has become more crucial (levy and Williams, 2004). Appreciate the highperforming employees and the analysis on low-performing employees will increase the employees' productivity together with companies' efficiency. This study, after outlined emotional labor, job satisfaction, burnout, and intention to resign, focuses on the methodology of the research.

From the perspective of the service sector, the satisfaction of the service recipients increases the interest on service quality; consequently, increasing importance of service quality boosts up the concern about the concept of emotional labor (Avci ve Boylu, 2010:4). In this context, emotional labor is accepted as a necessity of the employees' role, and it makes important the effort to show certain emotions claimed by the organization or the struggle to hide some emotions which is unwanted by the organization (Secer and Tinar, 2004:272). Because universities are the institutions providing educational services, it is situated in the service industry. The purpose of this study is to define the emotional performance of university employees from the highest to lowest. Hence, after the hardness level of the jobs, labour grading, wage settings and so on can be formed with a more objective approach.

\section{Conceptual Framework}

According to Kaynak and others (1998), performance is the concept that defines what extent a person can use the potential and real knowledge and ability to reach the targets and expectations. Performance evaluation is appropriated as an auxiliary tool in terms of organization and employee. Performance evaluation has two major aims. One of these aims is the obtaining information about the performance of work to help taking administrative decisions. The decisions on the wage rising, bonus, education, discipline, promotion, career planning, and other administrative activities usually depend on the information getting from performance evaluations. The management team of an organization should not take critical decisions without the information obtained from performance evaluation. As with other policies related to human resources, performance evaluations are organized in accordance with legal standards which prevent the discriminations against any groups (Micolo, 1993). Second objective of evaluating the performance is the provide feedback on the extent to which closer to standards in job description and analysis. The feedback can be beneficial when supported with positive approach and vocational training. Most employees like such constructive and confidence enhancing feedback. Employees can see how they progress in their career thanks to this kind of feedback. For instance, the feedback can help on whether an employee can be ready to take bigger responsibility or should have training to keep on current level (Palmer, 1993).

Furthermore, it is stated that two categories of job performance can be differed from many jobs. First category is to give clear directions of task and duties in job descriptions. Second category is aspects of performance occurred because of social orders of the job and work environment. Consequently, social effectiveness is an outstanding feature of social contextual performance (Murphy and Cleveland, 1995). For instance, the effectiveness can arise when employees can develop and keep pleasant relations with colleagues in job environment. 
The attention on emotions has been growing in work environment, and certain studies show that the display of decent emotions cause the great success of employees and the distribution of rewards by others. Staw, Sutton, and Pelled (1994) discovered that employee's remuneration is predicted by positive effects of emotions. Also, Staw and Barsade (1993) indicated that displaying positive emotions in the workplace tended to obtain supervisors' higher performance evaluations.

Performance evaluation is an arguable emotional experience. During the evaluation, employees' jobs are directly evaluated by one or more evaluators. These evaluations have significant effects on employees' psychological welfare, social status, continuity of employment in organization (Gerald, 2008).

Emotional Labor: "Emotional labor is a form of labor exerted by the employees who are expected to have a close relationship with customers. Also, it comprises the conversion of the emotions"(Kalfa ve Topates, 2009: 425). The conception of the emotional labor is defined differently by scholars. According to Ozkaplan (2009: 19), "emotional labor is a part of pack which the companies sell". In addition, emotions workers are selling their smiles like the selling the arm strength for industrial workers or the selling the brain power for information technology workers. Ashforth and Humphrey (1993: 90) inspected the Emotional Labor with the framework of social identity theory. In the frame, emotional labor is stated as an action to demonstrate proper emotion.

Morris and Feldman (1996: 987) defines the emotional labor as effort, planning, and controlling for showing the emotion demanded by the company during interpersonal interaction process. Grandey (1999:8) states that the emotional labor is a regulation of both emotions and behaviors, which serve the company's aims by emphasizing the rules of showing the emotions. It is claimed that there is a close relationship between emotions and business performance in the workplace (Cote and Miners:2006).

Job Satisfaction: There is a mental attitude developed by employees over time about job and relations in the workplace. To form the mental attitude, the knowledge about the job, the approaches on the result of the job, the conditions of the business environment have a substantial role. These attitudes can be either positive or negative. If the attitude of the employee is a positive, the attitude can be considered as job satisfaction, or vice versa (Barutcugil, 2004:388). The satisfaction or dissatisfaction reflects a general attitude of employees to their jobs. In other words, these positive and negative attitudes can be evaluated as the products of the feelings and thoughts of employees about the jobs, colleagues, and business environments (Solmus, 2004:186). Moreover, there are considerable studies showing that there are any relations between job satisfaction and job performance (Judge and others, 2001).

Burnout: In 1970's, it had been stood out different responses to the problems of psychological, behavioral, and physical, which caused by organizational sources of stress, and these different reactions are called "Burnout". The burnout was revealed after frequent and intense interactions with people encountered due to the job, and this feature distinguishes burnout from the other reactions originated organizational stressors (Torun, 1997). To determine the levels of burnout, it is benefitted a burnout inventory developed by Masclah. According to Masclah, burnout is defined as a status resulted from a long time working in the places demanded the intensive emotional requests. The emotional requests always stimulate physical wear, despair, hopelessness, and disappointment. Furthermore, after these attitudes appear, employees always tend to develop negative attitudes against the job, business environment, and life (Cokluk, 2000). 
Intention to Resign: Job satisfaction and intention to resign are located at the center of interest for many industrial and organizational psychologists, administrative scientists, and sociologists. The reason of this concern is based on the findings of empirical researches proving that intention to resign negatively affects the strength and efficiency of the organization (Samad, 2006). The intention of the employees leads to a number of such practical problems as loss of ability, employing additional staffs, and administration cost. Environmental factors affecting their intention to leave the job are organizational culture and values, working relationships with colleagues, job / role demands and expectations, career development opportunities, and autonomy (Takase, et al, 2005). When determining the performance of business behaviors of employees, some cases (emotional labor and job satisfaction) are required to be high while expecting that the certain the situations like burnout and intention to resign are low.

\section{Research Methodology}

The Universe and Sample of Research: The research is a descriptive study. First of all, the questionnaire forms are allocated to administrative staffs in Bartin University, which the forms consist of particular statements such as emotional labor, burnout, intention to quit the job, and job satisfaction. Bartin University has 180 administrative staffs, and 76 of them accepted to attend the research by filling out the survey. The universe of the research is the administrative staffs employed by Bartin University. While determining the sample, it is made the total number sampling, and rate of return the survey is $45 \%$.

Data Collection Tool: the scales about emotional labor in questionnaire forms were prepared by benefitting from the scale of Chu and Murmann (2006). In addition, it is used the scales of emotional labor for tourism employees with 12 questions created by Pala and Tepeci (2008) and Boylu and Avc1 (2010) adapted from Chu and Murmann Scale. Regarding burnout, the scale was used, which is developed by Maslach and Jackson (1981) and adapted to Turkish with 22 questions by Ergin (1992). The Minnesota Satisfaction Questionnaire developed by Weis, Dawis, England, and Lofquist (1967) and its adaptation created by Baycan (1985) with 20 questions were benefitted for evaluating the job satisfaction. The scale is widely used in order to survey the job satisfaction the employees working for hotel companies, travel agencies, information technology businesses, and other industries. The statements about intention to resign were taken from a scale of Blau and Boal (1989) which adapted to Turkish by Zayas (2006) and Yalçın (2010) with 5 questions scale.

While inputting the data to statistics software, the negative statements in the scales were inputted with reverse the coding.

\section{Data Analysis}

First, questionnaire forms obtained from administrative personnel are transferred to computer. Then, the order among workers is found by using ENTROPY weighting method and TOPSIS method.

Weighting: ENTROPY Method: Now, we give the process of assigning weighting value for criteria via entropy method (Alp, Öztel, \& M. Said, 2015; Hwang \& Yoon, 1981; Islamoglu, Apan, \& Oztel, 2015; Öztel, Köse, \& Aytekin, 2012). Let $m x n$ dimensional $D$ be decision matrix with $m$ alternative and $n$ criteria as below; 
(1)

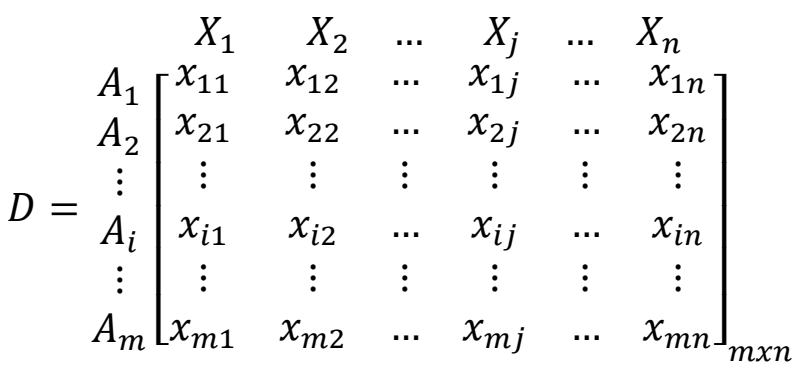

Here, $x_{i j}$ is the success value of $i$. alternative with respect to $j$. criterion where $i=1,2, \ldots, m$ and $j=1,2, \ldots, n$.

Values at $A_{i}$ row show the success value of $i$. alternative with respect to all criteria, values at $X_{j}$ column show the success value of all alternative according to $j$. criteria.

Since criteria have different scales, first we need to normalize them for evaluation. For this, below equality can be used;

$$
r_{i j}=\frac{x_{i j}}{\sum_{p=1}^{m} x_{p j}}, i=1,2, \ldots, m, j=1,2, \ldots, n .
$$

$R=\left[r_{i j}\right]_{m \times n}$ normalized matrix is obtained with this equality. Measurement of uncertainty or entropy value for all criteria is found with the equality below:

$1,2, \ldots, n$.

$$
e_{j}=-k \sum_{i=1}^{m} r_{i j} \ln r_{i j}, \quad j=
$$

Here $k$ value is constant defined as $k=\frac{1}{\ln m}$ and $0 \leq e_{j} \leq 1$ is guaranteed. $e_{j}$ is entropy value of $j$. criteria.

Now we can define degree of diversification $d_{j}$, for each criterion by using entropy value.

$$
d_{j}=1-e_{j}, \quad j=1,2, \ldots, n
$$

Weighting values of criteria is computed by dividing degree of diversification of each criterion with total degree of diversification. 


$$
W_{j}=\frac{d_{j}}{\sum_{p=1}^{n} d_{j}} \quad, \quad j=1,2, \ldots, n
$$

$$
W_{j} \text { is weight of } j \text {. criterion and } \sum_{j=1}^{n} W_{j}=1 \text { is obvious. }
$$

TOPSIS Method: Technique for Order Preference by Similarity to Ideal Solution (TOPSIS) method improved by Hwang \& Yoon (Hwang \& Yoon, 1981) is based on to choose the alternative which is the closest to ideal solution and the farthest to anti-ideal solution. The steps of this method is given below (Hwang \& Yoon, 1981; Islamoglu et al., 2015):

Step 1: Obtaining normalized decision matrix:

$R=\left[r_{i j}\right]_{m \times n}$ normalised decision matrix is obtained with the following formula.

$$
r_{i j}=\frac{x_{i j}}{\sqrt{\sum_{p=1}^{m}\left(x_{p j}\right)^{2}}}, i=1,2, \ldots, m, j=1,2, \ldots, n
$$

(6)

Step 2: Building weighted normalized decision matrix:

$V=\left[v_{i j}\right]_{m \times n}$ weighted normalized matrix is obtained via

$v_{i j}=w_{j} r_{i j}, i=1,2, \ldots, m, j=1,2, \ldots, n$

where $w_{j}$ is weighting value of $j$. criterion found by entropy method.

Step 3: Defining ideal and negative-ideal solutions:

Let two artificial $A^{*}$ (ideal solution) and $A^{-}$(negative-ideal solution) be as below:

$$
A^{*}=\left\{\left(\max _{i} v_{i j} \mid j \in J\right),\left(\min _{i} v_{i j} \mid j \in J^{\prime}\right) \mid i=1,2, \ldots, m\right\}=\left\{v_{1}^{*}, v_{2}^{*}, \ldots, v_{j}^{*}, \ldots, v_{n}^{*}\right\}
$$

$$
A^{-}=\left\{\left(\min _{i} v_{i j} \mid j \in J\right),\left(\max _{i} v_{i j} \mid j \in J^{\prime}\right) \mid i=1,2, \ldots, m\right\}=\left\{v_{1}^{-}, v_{2}^{-}, \ldots, v_{j}^{-}, \ldots, v_{n}^{-}\right\}
$$

where

$J=\{j=1,2, \ldots, n \mid$ when the utility criteria $\}$

$J^{\prime}=\{j=1,2, \ldots, n \mid$ when the cost criteria $\}$

Step 4: Computation of discrimination measure: 
Discrimination measure from ideal solution and discrimination measure from antiideal solution for each alternative are given below:

$$
\begin{aligned}
& S_{i^{*}}=\sqrt{\sum_{j=1}^{n}\left(v_{i j}-v_{j}^{*}\right)^{2}}, i=1,2, \ldots, m \\
& S_{i^{-}}=\sqrt{\sum_{j=1}^{n}\left(v_{i j}-v_{j}^{-}\right)^{2}}, i=1,2, \ldots, m
\end{aligned}
$$

Step 5: Computing relative proximity to ideal solution:

Relative proximity to ideal solution $A^{*}$ of $i$. alternative is defined as:

(12)

$$
C_{i^{*}}=S_{i^{-}} /\left(S_{i^{*}}-S_{i^{-}}\right), 0<C_{i^{*}}<1, i=1,2, \ldots, m
$$

Step 6: Order of Preference:

Preferences are ordered by sorting $C_{i^{*}}$ values from high to low.

\section{Application}

Table 1. Entropy weights for intention to leave

\begin{tabular}{|l|l|l|l|l|l|}
\hline & 1 question & 2. question & 3. question & 4. question & 5. question \\
\hline Weights & 0,160062 & 0,214923 & 0,202968 & 0,195537 & 0,22651 \\
\hline
\end{tabular}

According to Table 1 above, 2th and 5th questions are the most important questions.

Table 2. Entropy weights for emotional labor

\begin{tabular}{|l|l|l|l|l|l|l|}
\hline Questions & 1 & 2 & 3 & 4 & 5 & 6 \\
\hline Weights & 0,041228 & 0,079838 & 0,059972 & 0,068571 & 0,102649 & 0,056611 \\
\hline Questions & 7 & 8 & 9 & 10 & 11 & 12 \\
\hline Weights & 0,078519 & 0,134896 & 0,068413 & 0,122489 & 0,124629 & 0,062186 \\
\hline
\end{tabular}

According to Table 2 above, 5, 8, 10 and 11th questions are outstanding.

Table 3. Entropy weights for job satisfaction

\begin{tabular}{|l|l|l|l|l|l|l|l|}
\hline Questions & 1. Question & 2. Question & 3. Question & 4. Question & 5. Question & 6. Question & 7. Question \\
\hline Weights & 0,053425 & 0,020866 & 0,049563 & 0,03373 & 0,043322 & 0,037093 & 0,05641 \\
\hline Questions & 8. Question & 9. Question & 10. Question & 11. Question & 12. Question & 13 . Question & 14. Question \\
\hline Weights & 0,071918 & 0,045495 & 0,038815 & 0,061741 & 0,070155 & 0,075369 & 0,064993 \\
\hline Questions & $\begin{array}{l}15 . \\
\text { Question }\end{array}$ & 16. Question & 17. Question & 18. Question & 19. Question & 20. Question & \\
\hline Weights & 0,051837 & 0,055335 & 0,042997 & 0,05092 & 0,042412 & 0,033603 & \\
\hline
\end{tabular}


According to Table 3, 8, 11, 12, 13, and 14th questions are the most important ones.

Table 4. Entropy weights for job burnout

\begin{tabular}{|l|l|l|l|l|l|l|l|l|}
\hline Questions & 1. question & 2. question & 3. question & 4. question & 5. question & 6. question & 7. question & 8 . question \\
\hline Weights & 0,046233 & 0,036385 & 0,043914 & 0,015551 & 0,048415 & 0,039681 & 0,060276 & 0,055412 \\
\hline Questions & 9. question & 10. question & 11. question & 12. question & 13 . question & 14 . question & 15. question & 16. question \\
\hline Weights & 0,055889 & 0,066364 & 0,06703 & 0,029619 & 0,048769 & 0,034749 & 0,048854 & 1,048854 \\
\hline Questions & 17. question & 18. question & 19. question & 20. question & 21. question & 22. question & & \\
\hline Weights & 0,043325 & 0,019808 & 0,0414 & 0,040157 & 0,041356 & 0,076478 & & \\
\hline
\end{tabular}

It is seen from Table 4 that $7,10,11,16$, and 22th questions are the most important ones.

Table 5. Weighted total success values

\begin{tabular}{|c|c|c|c|c|}
\hline Survey Order No & Burnout & Job Satisfaction & Emotional Labor & Intent To Leave \\
\hline 1 & 2,727800285 & 2,863304458 & 3,908676217 & 1,480185432 \\
\hline 2 & 3,669956538 & 3,247334347 & 3,056665147 & 2,054493123 \\
\hline 3 & 2,180135064 & 3,579465772 & 3,789312207 & 1,640247243 \\
\hline 4 & 2,675757656 & 2,992222373 & 2,898260953 & 2,695621076 \\
\hline 5 & 2,072591988 & 3 & 3 & 3 \\
\hline 6 & 1,650402892 & 4,167780917 & 4,052718641 & 1,640247243 \\
\hline 7 & 2,186993008 & 3,325233379 & 3,936678095 & 1 \\
\hline 8 & 3,158467284 & 2,385156534 & 2,817002796 & 4,405957559 \\
\hline 9 & 3,507474163 & 3,053425036 & 2,659021553 & 3,210397629 \\
\hline 10 & 2,490205563 & 2,964769509 & 3,12813716 & 3,066448485 \\
\hline 11 & 3,070416407 & 3,261281187 & 1,936208747 & 2,394347686 \\
\hline 12 & 2,374853653 & 3,856957203 & 4,030836375 & 1,160061811 \\
\hline 13 & 2,445776244 & 3,21697998 & 3,487414862 & 2,320123621 \\
\hline 14 & 2,439483511 & 3,819766723 & 3,86536493 & 1,480185432 \\
\hline 15 & 1,468334053 & 2,844314231 & 3,012686558 & 1,20296754 \\
\hline 16 & 2,794745702 & 3,36028409 & 3,481463581 & 1,933551515 \\
\hline 17 & 1,535578238 & 3,898287547 & 4,274345077 & 1 \\
\hline 18 & 2,557230183 & 2,453500633 & 3,398996285 & 1 \\
\hline 19 & 3,07795089 & 2,963310839 & 2,739519114 & 3,382414803 \\
\hline 20 & 3,874784187 & 2,04460572 & 2,936049093 & 3,968677856 \\
\hline 21 & 2,533166672 & 3,083263173 & 3,533892404 & 1,160061811 \\
\hline 22 & 3,306454178 & 1,39526066 & 2,691752447 & 5 \\
\hline 23 & 3,287465476 & 1,822063043 & 3,162110791 & 4,839938189 \\
\hline 24 & 1,737962313 & 3,520938547 & 3,298017776 & 1 \\
\hline 25 & 3,262296906 & 3,53102296 & 2,767546369 & 2,577952253 \\
\hline 26 & 2,964109647 & 2,736918734 & 3,515784473 & 1 \\
\hline 27 & 2,256828624 & 2,736918734 & 3,233957168 & 1 \\
\hline
\end{tabular}




\begin{tabular}{|c|c|c|c|c|}
\hline 28 & 2,812276163 & 2,959906164 & 4,121784285 & 1,640247243 \\
\hline 29 & 3,685865831 & 2,013082277 & 3,847718883 & 2,702906393 \\
\hline 30 & 2,69340004 & 3,095192683 & 2,875906078 & 3,441433199 \\
\hline 31 & 1,588793755 & 4,232375378 & 2,997983375 & 1 \\
\hline 32 & 2,752648348 & 2,475421115 & 2,536586929 & 1 \\
\hline 33 & 2,869341635 & 2,553552822 & 2,497651074 & 1 \\
\hline 34 & 2,150843666 & 3,388808723 & 2,642749486 & 1,718628612 \\
\hline 35 & 3,35022852 & 2,062802939 & 3,12678782 & 4,18812984 \\
\hline 36 & 2,309525485 & 3,517463072 & 3,068765452 & 1 \\
\hline 37 & 1,989699242 & 4,00908301 & 3,086511609 & 1,640247243 \\
\hline 38 & 1,989699242 & 4,00908301 & 3,086511609 & 1,640247243 \\
\hline 39 & 2,061183771 & 2,583662002 & 4,419188967 & 1,320123621 \\
\hline 40 & 2,072607195 & 3,31070861 & 3,277202415 & 1 \\
\hline 41 & 2,948839561 & 2,769675021 & 2,355487313 & 1,374984713 \\
\hline 42 & 3,090787907 & 2,776186005 & 3,127780648 & 3,09688611 \\
\hline 43 & 2,12544686 & 2,706118882 & 3,402829998 & 1,160061811 \\
\hline 44 & 3,033860192 & 3,790325665 & 3,340480317 & 2,285015951 \\
\hline 45 & 2,226671122 & 3,234461667 & 4,821945358 & 1,855170145 \\
\hline 46 & 2,895480053 & 2,796297979 & 2,926509025 & 4,804462549 \\
\hline 47 & 2,608529193 & 3,616571834 & 3,218098264 & 2,019753421 \\
\hline 48 & 2,02146903 & 4,256774758 & 3,065382826 & 1 \\
\hline 50 & 2,931789797 & 1,984974018 & 3,771078389 & 4,191380146 \\
\hline 52 & 1,80747647 & 2,731252358 & 2,972784874 & 3,320123621 \\
\hline 53 & 2,586584059 & 2,302196618 & 2,899733112 & 1,620857982 \\
\hline 54 & 2,574386452 & 3,519548481 & 3,322965497 & 1,320123621 \\
\hline 55 & 3,601622473 & 1,6923927 & 2,890418458 & 1 \\
\hline 57 & 2,035164791 & 2,550482122 & 3,179741677 & 1,160061811 \\
\hline 58 & 2,393371625 & 2,768207213 & 3,584760716 & 1 \\
\hline 59 & 3,21938535 & 2,302956709 & 3 & 1,640247243 \\
\hline 60 & 1,629897976 & 4,012616346 & 3,390085326 & 1 \\
\hline 61 & 2,02018399 & 2,561309395 & 4,155410991 & 1,480185432 \\
\hline 62 & 3,231742894 & 2,741070089 & 2,920161728 & 2,53088922 \\
\hline 64 & 2,66071225 & 2,757086011 & 2,160806244 & 1 \\
\hline 65 & 2,074084606 & 3,697581068 & 3,289442504 & 1,160061811 \\
\hline 66 & 2,754538441 & 2,684164099 & 3,156854279 & 2,210765598 \\
\hline 67 & 2,994980792 & 2,634601276 & 3,4682976 & 2,210765598 \\
\hline 68 & 1,900489939 & 4,529269876 & 4,151114243 & 1 \\
\hline 69 & 2,126951265 & 3,72306329 & 3,835583795 & 1,160061811 \\
\hline 70 & 2,110089402 & 2,443257098 & 2,951733441 & 4,160061811 \\
\hline 71 & 3,544462228 & 2,320510425 & 4,065368244 & 4,367186655 \\
\hline 72 & 2,875188299 & 1,637913225 & 2,996424131 & 3,773835194 \\
\hline
\end{tabular}




\begin{tabular}{|l|l|l|l|l|}
\hline 73 & 2,858674963 & 2,491342376 & 3,101200603 & 3,160061811 \\
\hline 74 & 3,310468656 & 2,006371925 & 3,333381845 & 3,320491591 \\
\hline 75 & 2,782247106 & 2,709947799 & 1,564490766 & 4,351441957 \\
\hline 76 & 2,06621623 & 2,6540566 & 3,622567549 & 1 \\
\hline
\end{tabular}

Weighted average of participants' statements about feelings is shown in Table 5.

Table 6. The Performance Ranking Calculated by TOPSIS

\begin{tabular}{|c|c|c|c|}
\hline Survey Order No & Ranking & Survey Order No & Ranking \\
\hline 1 & 31 & 37 & 33 \\
\hline 2 & 43 & 38 & 34 \\
\hline 3 & 35 & 39 & 26 \\
\hline 4 & 51 & 40 & 8 \\
\hline 5 & 53 & 41 & 29 \\
\hline 6 & 32 & 42 & 55 \\
\hline 7 & 7 & 43 & 17 \\
\hline 8 & 69 & 44 & 46 \\
\hline 9 & 57 & 45 & 40 \\
\hline 10 & 54 & 46 & 70 \\
\hline 11 & 48 & 47 & 42 \\
\hline 12 & 11 & 48 & 5 \\
\hline 13 & 47 & 50 & 65 \\
\hline 14 & 28 & 52 & 58 \\
\hline 15 & 18 & 53 & 37 \\
\hline 16 & 41 & 54 & 25 \\
\hline 17 & 2 & 55 & 27 \\
\hline 18 & 19 & 57 & 21 \\
\hline 19 & 60 & 58 & 14 \\
\hline 20 & 63 & 59 & 39 \\
\hline 21 & 16 & 60 & 3 \\
\hline 22 & 72 & 61 & 30 \\
\hline 23 & 71 & 62 & 49 \\
\hline 24 & 6 & 64 & 22 \\
\hline 25 & 50 & 65 & 12 \\
\hline 26 & 20 & 66 & 44 \\
\hline 27 & 15 & 67 & 45 \\
\hline 28 & 36 & 68 & 1 \\
\hline 29 & 52 & 69 & 10 \\
\hline 30 & 61 & 70 & 64 \\
\hline
\end{tabular}




\begin{tabular}{|l|c|c|c|}
\hline 31 & 4 & 71 & 68 \\
\hline 32 & 23 & 72 & 62 \\
\hline 33 & 24 & 73 & 56 \\
\hline 34 & 38 & 74 & 59 \\
\hline 35 & 66 & 75 & 67 \\
\hline 36 & 9 & 76 & 13 \\
\hline
\end{tabular}

\section{Conclusions}

The productivity of human resources is measured only by observing the job-related performance of employees. The one of the best way to measure is to set up a regular performance evaluation system. Performance evaluation in businesses has been seen as an important issue. In this study, it is aimed to numerically measure a qualitative concept as the performance of job behaviors of employees.

By using weighting method, the importance level of questions is determined, and scale values for each scale are separately and objectively defined. Since the most proper situations in the scales are in opposite directions, TOPSIS methods accepted as multi-criteria decisions making methods is used to reduce all scales to one value. Which criteria would be used to evaluate the performance and what rate of the criteria's impact on the performance are decision points. TOPSIS is a widely known and benefitted technique in multi-criteria decision making. Together with, when the system is objective and self-consistent, a trusted application is occurred. TOPSIS can find the best option by evaluating multiple alternatives in terms of multi-criteria. To measure emotions numerically is a tough deal. So, this research offers an alternative way to measure emotions of employees. In the future studies, more comprehensive scale can be used by including the other concepts of job behaviors.

As the result of analysis, the employee showing highly emotional performance is number 68 who is 38 years old male, married, and graduated from a University. Second high performance person is number 17. Third one is number 60 who is male, computer operator, and institute employee. Fourth high one is number 31 who is 41 years old male, married, graduate, and a branch manager at Health Culture Sport Department. Fifth one can be observed as number 48 .

\section{References}

Alp, İ., Öztel, A., \& M. Said, K. (2015). Entropi Tabanlı MAUT Yöntemi İle Kurumsal Sürdürülebilirlik Performansı Ölçümü: Bir Vaka Çalışması. The International Journal of Economic and Social Research, 11(2), 65-81.

Avcı, U. Ve Boylu, Y. (2010). Türk Turizm Çalışanları İçin Duygusal Emek Ölçeği Geçerlemesi. SOID Seyahat ve Otel İşletmeciliği Dergisi. 7(2)

B.M. Staw, R. Sutton, L. Pelled Employee positive emotions and favorable outcomes at the workplace Organization Science, 5 (1994), pp. 51-71

B.M. Staw, S.G. Barsade Affect and managerial performance: A test of the sadder-but-wiser vs. happier-and-smarter hypothesis Administrative Science Quarterly, 38 (1993), pp. 304-331

Barutçugil, İ. (2004). Organizasyonlarda Duyguların Yönetimi. Kariyer Yayınları: İstanbul. 
Baycan, F.A., (1985). Farklı Gruplarda Çalışan Gruplarda İş Doyumunun Bazı Yönlerinin Analizi. Published Doctoral Dissertation. Boğaziçi University, Istanbul.

Blau, G., \& Boal, K. (1989). Using job involvement and organizational commitment interactively to predict turnover. Journal of management, 15(1), 115-127.

Chu, K. Hei-Lin ve Murrmann, K. S. (2006). Development and validation of the hospitality emotional labor scale. Tourism Management. 27(6), 1181-1191

Çokluk, Ö. (2000). Örgütlerde Tükenmişlik: Yönetimde Çağdaş Yaklaşımlar. (Edit: Cevat Elma ve Kamile Demir). Ankara: Anı Yayıncılık.

Cote, S., \& Miners, C. T. (2006). Emotional intelligence, cognitive intelligence, and job performance. Administrative Science Quarterly, 51(1), 1-28.

Ergin, C. (1992). Doktor ve Hemşirelerde Tükenmişlik ve Maslach Tükenmişlik Ölçeğinin Uyarlanması. iç. Rüveyda BAYRAKTAR ve İhsan DAĞ (Ed.), VII. Ulusal Psikoloji Kongresi Bilimsel Çalışmaları. Ankara: Türk Psikologlar Derneği Yayını, ss. 143154.

Gerald R. Ferris, Timothy P. Munyon, Kevin Basik, M. Ronald Buckley, The performance evaluation context: Social, emotional, cognitive, political, and relationship components, Human Resource Management Review, Volume 18, Issue 3, September 2008, Pages 146-163, ISSN 1053-4822, http://dx.doi.org/10.1016/j.hrmr.2008.07.006.

Grandey, A. A. (1999). The Effects of Emotional Labor: Employee Attitudes, Stress and Performance. Yayınlanmamış Doktora Tezi. Colorado State University, USA.

Gursoy, D., Boylu, Y. ve Avci, U. (2011). Identifying the Complex Relationships Among Emotional Labor and Its Correlates. International Journal of Hospitalitiy Management. 30, 7983-7984.

Hochschild, A. R. (1979). Emotion Work, Feeling Rules And Social Structure. American Journal of Sociology. 85 (3), 551-575.

Hochschild, R. A. (1983). The managed hearth: Commercialization of human feeling. Berkeley: University of California Pres.

Hwang, C.-L., \& Yoon, K. (1981). Lecture Notes in Economics and Mathematical Systems: Multiple Attribute Decision Making: Methods and Appllication: Springer Verlag.

Islamoglu, M., Apan, M., \& Oztel, A. (2015). An Evaluation of the Financial Performance of REITs in Borsa Istanbul: A Case Study Using the Entropy-Based TOPSIS Method. International Journal of Financial Research, 6(2), p124.

Judge, Timothy A.; Thoresen, Carl J.; Bono, Joyce E.; Patton, Gregory K. (2001). The job satisfaction-job performance relationship: A qualitative and quantitative review. Psychological Bulletin, Vol 127(3), 376-407. http://dx.doi.org/10.1037/0033$\underline{2909.127 .3 .376}$

K.R. Murphy, J.N. Cleveland Understanding performance appraisal: Social, organizational, and goal-based perspectives Sage Publications, Thousand Oaks, CA (1995)

Kaynak, T ve diğ. (1998). İnsan Kaynakları Yönetimi. İstanbul Üniversitesi İşletme Fakültesi Yayınları, İstanbul.

Levy and Williams, 2004 P.E. Levy, J.R. Williams The social context of performance appraisal: A review and framework for the future Journal of Management, 30 (2004), pp. 881-905 
Maslach, C. ve Jackson, S. E. (1981). The Measurement of Experienced Burnout. Journal of Occupational Behaviour. 2(2), 99-113.

Micolo, A. M. (1993). Suggestions for achieving a strategic partnership. Hr Focus, 70(9), 22.

Morris, J. A. and Feldman, D. C. (1996). The Dimensions, Antecedents, And Consequences Of Emotional Labor, Academy of Management Journal. 21, 989-1010.

Özdemir, M. S. (2002). Bir İşletmede Analitik Hiyerarşi Süreci Kullanılarak Performans Değerleme Sistemi Tasarımı. Endüstri Mühendisliği Dergisi,(2)11, 2-11.

Özkaplan, N. (2009). Duygusal Emek ve Kadın İşi/Erkek İşi. Çalışma ve Toplum. 2, 15-24.

Öztel, A., Köse, M. S., \& Aytekin, İ. (2012). Kurumsal Sürdürülebilirlik Performansının Ölçümü İçin Çok Kriterli Bir Çerçeve: Henkel Örneği. Tarih Kültür ve Sanat Araştırmaları Dergisi, 1(4), 32-44.

Pala, T. ve Tepeci, M. (2009). Turizm İşletmelerinde Çalışanların Duygusal Emek Düzeyi ve Duygusal Emeğin Çalışanların Tutumlarına Etkisi. 17. Ulusal Yönetim ve Organizasyon Kongresi. 21-23 Mayıs 2009, Eskişehir, 113-119.

Palmer, M.J.(1993). Performans Değerlendirmeleri. Rota Yayınları, 1.Bask1, 1993

Samad, S. (2006). Predicting Turnover Intentions: The Case of Malaysian Government Doctors. The Journal of American Academy of Business, Cambridge. 8(2), 113-119.

Solmuş T. (2004). İş Yaşamında Duygular ve Kişiler Arası İlişkiler. Ankara: Beta Yayınları.

Takase, M., Maude, P. And Manıas, E. (2005). Nurses' Job Dissatisfaction and Turnover Intention: Methodological Myths and an Alternative Approach. Nursing and Health Sciences.7, 209-217.

Topateş, H. ve Kalfa, A. (2009). Yeni Çalışma İlişkileri Bağlamında Örgütsel Yurttaşlık ve Duygusal Emek. Uluslararası Sosyal Haklar Sempozyumu. 22-23 Ekim, Akdeniz Üniversitesi, 423-431.

Torun, A. (1997). Stres ve Tükenmişlik. Endüstri ve Örgüt Psikolojisi içinde, Ed.Suna Tevrüz, 2.Baskı, Türk Psikologlar Derneği ve Kalite Derneği Ortak Yayını, İstanbul, 43-53.

Weiss, D.J., Dawis, R.V., England, G.W., ve Lofquist, L. H. (1967). Manual for The Minnesota Satisfaction Questionnaire (Minnesota Studies in Vocational Rehabilitation, No. 22), Minneapolis: University of Minnesota.

Yıldız, O., Dağdeviren, M., Çetinyokuş, T. (2008). İşgören Performansının Değerlendirilmesi için Bir Karar Destek Sistemi ve Uygulaması. Gazi Üniversitesi Mühendislik ve Mimarlık Fakültesi Dergisi. (23)1. 239-248

Zayas, M. (2006). Psychological determinants of commitment and attitudes toward work termination: the effect of locus of control on turnover intention. Published Master Dissertation. Marmara University, Istanbul. 